\title{
SOME LATE-HOLOCENE POLLEN DIAGRAMS FROM THE PEEL RAISED BOGS (SOUTHERN NETHERLANDS)
}

\author{
C. R. JANSSEN AND H. A. TEN HOVE
}

Botanical Museum and Herbarium, State University, Utrecht (The Netherlands)

(Received June 26, 1969)

\section{SUMMARY}

Three pollen diagrams from the Peel peatlands, a raised bog area in the southern part of The Netherlands reveal the post-Boreal vegetation history of that region. There are two or three land-occupation phases in the Neolithic and Bronze ages, that show but low values of terrestrial herbs. They are negatively correlated with Ulmus. The Fagus curve starts slightly below the first occupation phase at around 2500 B.C.

In the Subatlantic there is an Iron age and a Medieval occupation phase with higher values of terrestrial herbs. Fagus shows two maxima, one at the beginning of our era and another at around 700 A.D. The trend of the pollen curves for bog species is discussed in relation to bog development.

\section{INTRODUCTION}

The Peel peatlands on the frontier of the Brabant and Limburg provinces in The Netherlands came into existence after the Würm Glacial on the watershed between the Maas river and the North Brabant brook system (Fig.1).

According to VAN DER TOORN (1967) lake filling started in blocked drainage channels, but soon formation of lake sediments and peat began to fill these channels. Later in the Holocene, expansion of the peatland took place by the formation of raised bogs. Palynologists focussed their attention quite early on this area and EsHuis (1946) published an extensive pollen-analytical study of the Peel bogs in which he included most of the earlier work. With his work the main pollen-stratigraphy of the region was established. But because the actual work of Eshuis had been performed before and during the Second World War, his diagrams do not give adequate information on the fluctuations of the curves from herbaceous pollen grains. In the present study three peat cores were investigated pollenanalytically in order to establish the regional pollen sequence in this part of the country. 


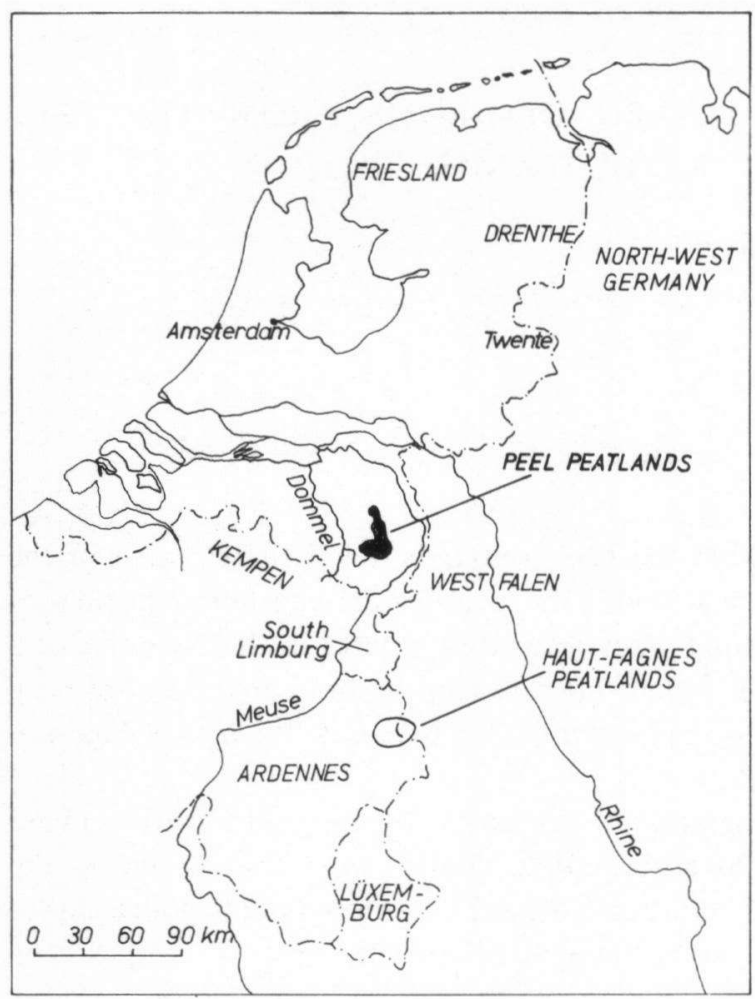

Fig.1. Map of The Netherlands and adjacent regions with the location of the Peel peatlands and other regions referred to in the text.

\section{Location of the cores}

The cores are located in the middle and southern peatlands (Fig.2) where drained remnants of the 'peatland still exist. The Griendsveen cores are located in the center of the peatland, the Ospelse Peel core close to the southern margin.

\section{MATERIALS AND METHODS}

Cores were taken with a Dachnowski peat sampler except for the upper 130 $\mathrm{cm}$ of the Ospelse Peel core. This section was cut from the wall of a former excavation site, a few meters from the coring site. Materials for pollen analysis were sampled in the laboratory. Treatment of the core samples included boiling with $10 \% \mathrm{KOH}$ for $1 \mathrm{~min}$, sieving the mixture through a screen and acetolysis at $95^{\circ} \mathrm{C}$ for $10 \mathrm{~min}$. The material was mounted in a $50 \%$ glycerol-water mixture, without stain. Whole number of slides were counted. 


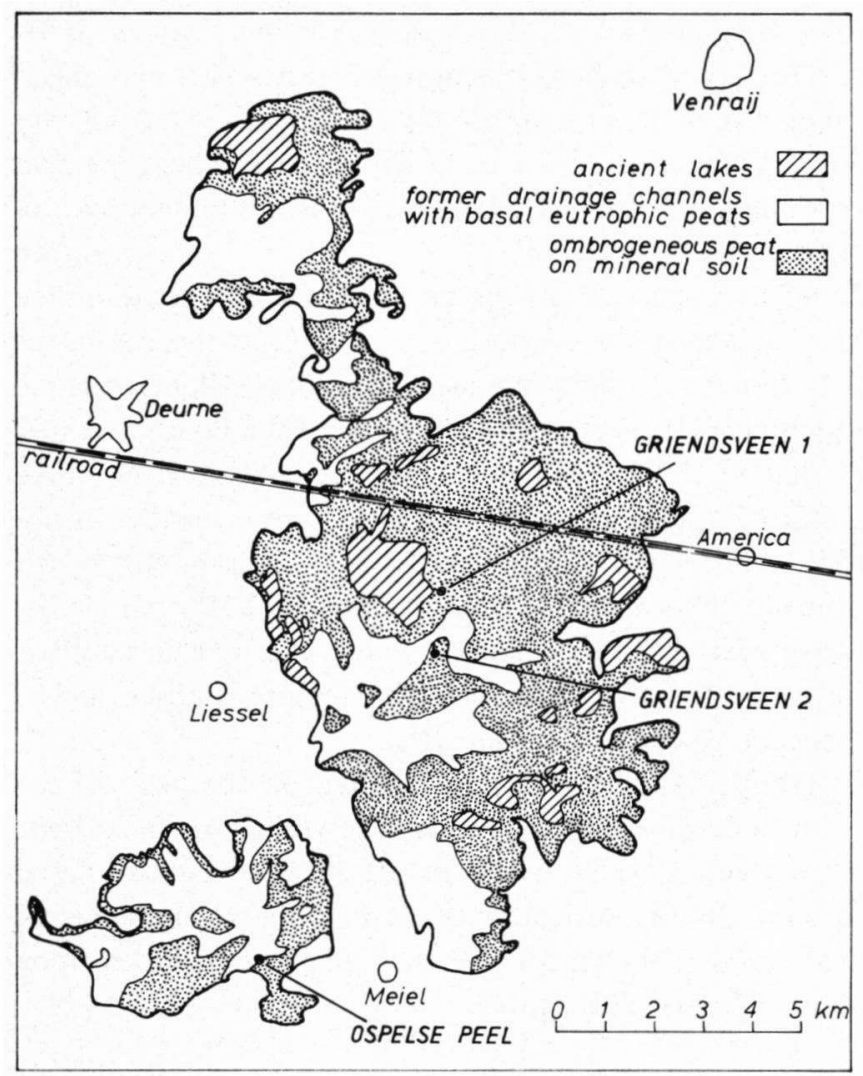

Fig.2. Location of cores in relation to types of peat stratigraphy according to VAN DER TOORN (1967).

POLlen diagrams (Fig.3, 4, 5)

Pollen types have been arranged in stratigraphic-ecologic groups in order to facilitate the evaluation of the diagrams. The pollen sum comprises the pollen types that are believed to originate from upland plants (group 1-4). A curve for total upland herbs is shown at the right side of the summary diagram. Since most of the peat is ombrogeneous in origin, the upland pollen types show values that are believed to be regional. Consequently the upland diagram may be considered a standard for the entire region. Groups 5-12 represent the pollen types which, at any time covered by the diagrams, may have been part of the local peat vegetation. In a particular zone, these types often show a local over-representation and have to be removed from a pollen sum that comprises regional types. But outside this particular zone they exhibit a regional pattern, as do the regular upland types. Types that have such a varying ecological significance are found in group 5 
(Ericaceae, Poaceae and Betula). The curve of the Ericaceae (mainly Calluna) starts to rise at the level where ombrogeneous bog development starts. This may mean local occurrence. Macroscopic remains of Calluna are present at these levels but not much. An exception is the peat at the basis of Griendsveen 1 , where the peat may be considered a true Calluna peat. Consequently there is a big maximum of this pollen type in zone IXa.

At Griendsveen 2 and at Ospelse Peel, the curve of the Ericaceae pollen grains often parallels that of upland herbs. At these sites, therefore, the ericaceous pollen grains may be partly of upland origin. An evaluation of the Poaceae curve is much more clear. Up to zone VIII most of the pollen from the Poaceae comes from Phragmites. Above that level the percentages are regional and the curve of the Poaceae parallels that of upland herbs. Betula may have occurred on uplands ( $B$. verrucosa) but in the lower part of the Ospelse Peel diagram part of the pollen grains may have come from local Betula trees. From zone VIII on, macroscopic remains of Betula have never been met. The curve is rather uncharacteristic except for a huge peak in zone IXc at Ospelse Peel. This feature is absent in the other diagrams and we suspect it to be local in character.

The percentages of groups 5-12 have been calculated on the basis of the upland pollen sum. The percentages of all the types are shown in two curves. The black curves and lined curves (with scale $5 \times$ exaggerated) show percentages based upon the upland pollen sum. In the Griendsveen 2 diagram a supplemental curve (without exaggerated scale) is shown for Corylus and Quercus based upon the upland pollen sum minus Pinus (see also p.16).

\section{PEAT-STRATIGRAPHY}

Part of the material of the cores has been investigated upon the composition of the parent material, important for the identification of the various peat types. The peat stratigraphy is listed below. The number of seeds and fruits found is placed between brackets.

Ospelse Peel (Fig.4)

0- $20 \mathrm{~cm}$ : Sphagnum-Carex-Phragmites peat, much desiccated; between 10-15 cm charred wood.

$20-27 \mathrm{~cm}$ : Sphagnum peat with some Sphagnum cuspidatum leaves, Eriophorum and Carex rootlets.

27- $33 \mathrm{~cm}$ : Eriophorum-Sphagnum peat with some Carex.

33- $40 \mathrm{~cm}$ : Eriophorum-Sphagnum peat; some Sphagnum papillosum leaves.

$40-50 \mathrm{~cm}$ : Eriophorum-Sphagnum papillosum peat; Andromeda polifolia $(1 \times)$.

$50-70 \mathrm{~cm}$ : Eriophorum peat; Carex rootlets and some twigs of Calluna present; not much Sphagnum. 
70- $80 \mathrm{~cm}$ : Eriophorum peat; Carex rootlets present; Andromeda polifolia $(1 \times)$.

$80-87 \mathrm{~cm}$ : Eriophorum peat; Andromeda polifolia $(12 \times)$.

87-100 cm: Sphagnum peat; not much Eriophorum and Carex; some Calluna twigs present; Andromeda polifolia ( $2 \times)$; one glume of a grass.

100-107 cm: Sphagnum peat; some of the leaves from Sphagnum cymbifolium.

107-114 cm: Sphagnum-Eriophorum-Carex peat; twigs of Calluna; Andromeda polifolia $(\mathrm{I} \times)$.

114-140 cm: Eriophorum-Carex peat; twigs of Calluna.

140-150 cm: Eriophorum-Sphagnum (partly $S$. cymbifolium) peat; Andromeda polifolia $(1 \times)$.

150-160 cm: Sphagnum peat, partly Sphagnum cuspidatum; Andromeda polifolia $(3 \times)$.

160-168 cm: Sphagnum-Scheuchzeria peat; Sphagnum cymbifolium abundant; Andromeda polifolia $(1 \times)$, Poaceae glumes $(5 \times)$.

168-180 cm: Scheuchzeria peat with but few Sphagnum leaves among which Sphagnum cymbifolium.

180-190 cm: Scheuchzeria-Eriophorum peat; seeds and fruits of Betula $(1 \times)$, Andromeda polifolia $(1 \times)$, Carex $(1 \times)$.

190-200 cm: Scheuchzeria peat; Comarum palustre $(2 \times)$.

200-207 cm: Scheuchzeria peat.

207-214 cm: Scheuchzeria-Eriophorum-Phragmites peat.

214-220 cm: Phragmites-Eriophorum-Scheuchzeria peat; some Carex rootlets.

$220-225 \mathrm{~cm}$ : Scheuchzeria-Eriophorum-Phragmites peat; Comarum palustre $(2 \times)$.

225-232 cm: Eriophorum-Scheuchzeria-Carex peat; Comarum palustre $(1 \times)$, Carex $(2 \times)$, Eriophorum $(2 \times)$.

232-240 cm: Eriophorum-Carex peat.

240-250 cm: Eriophorum-Carex-Phragmites peat; Scirpus $(1 \times)$.

250-260 cm: Eriophorum-Carex-Phragmites peat; Comarum palustre $(1 \times)$, Carex $(10 \times)$, Eriophorum $(2 \times)$.

260-267 cm: Alnus-Carex peat; some remains of Eriophorum and Phragmites; Carex $(12 \times)$, Comarum palustre $(2 \times)$, Betula $(4 \times)$, Lycopus $(1 \times)$.

267-275 cm: as above but without Phragmites; Comarum palustre $(3 \times)$, Betula $(2 \times)$, Lycopus $(3 \times)$, Carex $(4 \times)$.

275-305 cm: Alnus peat; between $280-290 \mathrm{~cm}$ a Lycopus seed; between $275-280$ cm wood of Alnus glutinosa.

305-308 cm: clayey Alnus peat; some gravel.

$308-311 \mathrm{~cm}$ : sandy clay with some gravel.

Griendsveen 1 (Fig.5)

0- $11 \mathrm{~cm}$ : sand from railroad grade.

11- $12 \mathrm{~cm}$ : charred wood. 
12- $50 \mathrm{~cm}$ : Sphagnum peat.

$50-58 \mathrm{~cm}$ : Sphagnum-Eriophorum peat.

58- $62 \mathrm{~cm}$ : Eriophorum-Sphagnum peat.

62- $64 \mathrm{~cm}$ : Sphagnum-Eriophorum peat with some Carex rootlets.

$64-68 \mathrm{~cm}$ : Sphagnum-Eriophorum peat.

68- $70 \mathrm{~cm}$ : Sphagnum peat with minor quantities of Carex and Eriophorum.

$70-74 \mathrm{~cm}$ : Sphagnum-Eriophorum peat with some Carex rootlets.

$74-81 \mathrm{~cm}$ : Calluna peat.

\section{Griendsveen 2 (Fig.5)}

0- $10 \mathrm{~cm}$ : sand.

10- $20 \mathrm{~cm}$ : Sphagnum-Eriophorum peat, rather undecomposed.

20- $40 \mathrm{~cm}$ : Eriophorum peat.

40- $45 \mathrm{~cm}$ : Sphagnum cuspidatum peat.

45- $60 \mathrm{~cm}$ : Sphagnum-Eriophorum peat, more decomposed than above.

$60-75 \mathrm{~cm}$ : pure Sphagnum peat.

75-182 cm: Sphagnum-Eriophorum peat in varying quantities of Sphagnum and Eriophorum; at $90 \mathrm{~cm}$ a recurrency surface.

182-195 cm: Carex-Sphagnum-Eriophorum peat; many Carex rootlets.

195-220 cm: Carex-Scheuchzeria peat; some Eriophorum.

220-230 cm: Carex peat.

230-240 cm: Carex peat with some Eriophorum.

240-245 cm: Carex peat; some remains of Eriophorum, Scheuchzeria and Sphagnum present.

245-258 cm: gyttja.

258-260 cm: sand with a few Carex rootlets.

THE ZONATION OF THE DIAGRAMS

In order to establish a framework for discussion, the diagrams have been zoned according to similar assemblage zones. The number of diagrams presented here is too small to allow a time-stratigraphic evaluation of some of the minor zones. The subdivisions of the zones, therefore, have to be considered as provisional. On the other hand the upland diagrams show such striking similarities, even in small detail, that we suspect them to reflect a similar regional pollen rain. The numbering of the zones follows Firbas (1949).

Atlantic (zone VII)

The pollen record starts in the Atlantic with Corylus, Quercus, Ulmus, Tilia and Fraxinus as the main tree-pollen types. Towards the upper part of the zone 
there is a rise of Corylus and a decline of Ulmus. A number of subzones has been established on the basis of the local peat development and thus does not have any time-stratigraphic implication.

\section{Subboreal (Zone VIII)}

The transition zone VII/VIII has been placed at a marked minimum of Ulmus, the first appearance of Plantago lanceolata and Cerealia and rised values of Pteridium. Just below that border the first pollen grains of Fagus are present. A ${ }^{14} \mathrm{C}$-date around the Pteridium maximum is $4510 \pm 85$ B.P.(GrN-5619). Ulmus thus starts to decline already before that date.

The Subboreal is characterized by the dominance of Corylus and (to a lesser extent) Quercus, by fluctuating values of Fraxinus and Ulmus and by low Fagus percentages. The zone may be divided into four subzones. In zone VIIIa Ulmus and Fraxinus reach a maximum after minimum values at the transition to the previous zone. There is a decline of Pinus at the top of the subzone. In zone $\mathrm{VIIIb}$ the pine valuesincrease, those of Corylus decrease. There is a slight temporary increase of Fagus. Zone VIIIc and VIIId are characterized by a decrease of Pinus but by a renewed increase of Corylus. In zone VIIId there is a slight rise of Fagus and a minimum of upland herbs.

At Ospelse Peel, however, there is a possibility of an overlap in the pollen stratigraphy. A ${ }^{14} \mathrm{C}$-date at $130 \mathrm{~cm}$, at the base of the section cut from a peat wall, revealed 2520 B.C. (GrN-5163), a date similar to that from the base of zone VIIIa. This is supported by the general course of the curves for Pinus, Ulmus and Corylus. However, the difference in the curves for Fagus, Pteridium and the Poaceae, seem to plead against the existence of an overlap in the diagram.

\section{Subatlantic (zone IX and $X$ )}

Zone IX is characterized by a strong decline of Corylus, the termination of the continuous Tilia curve and a general increase of Fagus and Carpinus. The zone may be divided into three subzones. Subzone IXa is transitional. The Tilia curve already is discontinuous, Fagus and Carpinus increase and Corylus drops from 40 to $20 \%$ (Griendsveen 1). In subzone IXb there is a maximum of Fagus and upland herbs. In subzone IXc upland herbs are at a minimum and the Fagus curve shows a second maximum (F-2). Finally, in zone X Fagus and Carpinus decrease and there is a strong increase of upland herbs. At Ospelse Peel the subzone marked VIIId poses a problem. There is already a fair amount of upland herbs and, therefore, one would be inclined to include this subzone in the Subatlantic. However, the Corylus values are not below $40 \%$ and Tilia is still continuously present. Inclusion in zone VIII, therefore, seems more reasonable. Subzone IXa found at Griendsveen 1, thus would be lacking at Ospelse Peel. 
This is confirmed by four ${ }^{14} \mathrm{C}$-dates. The age at the level of spectrum no. 22 is $3100 \pm 50$ B.P. (GrN-5621), that at the level of spectrum no. 24 is $3300 \pm 50$ B.P. (GrN-5161). The ages around the levels of spectrum no. 16 and 17 are resp. 1885 \pm 40 B.P. (GrN-5164) and $2090 \pm 70$ B.P. (GrN-5620). This suggests a gap of some 1000 years within a distance of $12 \mathrm{~cm}$ sediment. Possibly the gap exists between spectrum no. 19 and 20. Here Corylus suddenly drops from 40 to $20 \%$, a range nicely filled in the Griendsveen 1 diagram. A similar gap is present at the Griendsveen 2 diagram. Here also zone IXa is lacking, possibly even zone VIIId from Ospelse Peel. Such a gap in the peat stratigraphy at the base of zone IX is also present in some of Eshuis' diagrams (cf. WATERBOLK, 1954, pp.101-102).

DISCUSSION OF THE DIAGRAMS

\section{Pre-Subatlantic}

\section{Ulmus and land-occupation phases}

Since IVERSEN (1941) the border between the Atlantic and the Subboreal period is placed at the fall of Ulmus and the first appearance of pollen of Plantago lanceolata. Most of the ${ }^{14} \mathrm{C}$-dates obtained in western Europe are around 3250 B.C. (Nilsson, 1964). In the Ospelse Peel diagram the level just above the first appearance of Plantago lanceolata has been dated at 2540 B.C., thus rather late. But the appearance of Plantago is found at a level where Ulmus is already at a minimum. The start of the elm fall is earlier. In the Ospelse Peel diagram it happens roughly at the base of zone VIIc. There is at this level an increase of Artemisia and the Chenopodiaceae but Plantago is still lacking. The actual decline of Ulmus thus may not be connected with human interference. The date of 2520 B.C. of the first occupation phase may point to the Vlaardingen culture, a culture described from the western part of The Netherlands, but which also seems to be present in Brabant (VAN REGTEREN-ALTENA et al., 1962).

During zone VIII the Ulmus curve shows three maxima. Elsewhere in western Europe, especially in Ireland (SMITH, 1964) there is a clear correlation between the course of the Ulmus curve and that of Plantago lanceolata. In our diagrams this is not very obvious because Plantago remains low in percentages. There is, however, a correlation between Pteridium (pioneer after clearing)-Rumex acetosella-Cerealia and Ulmus. There are apparently three (or two, in case of an overlap) landoccupation phases connected with a decline of Ulmus. In the Ospelse Peel diagram they are numbered I-II-III. From the low Plantago values one might conclude that the land-occupation phases are like those described by TroelsSMITH (1955) from Switzerland and by VAN ZEIST (1959) from the northern Netherlands for the earliest agricultural cultures. According to them a low value of Plantago lanceolata would indicate that little pasture land was available. Cattle was kept inside enclosures. Apparently in the Peel region this kind of practice 
persisted during most of the Neolithic and Bronze-age periods. It is not until zone IXb (Roman-Iron age period) that higher values of Plantago lanceolata are found. This is confirmed by the values for Plantago lanceolata found in burial mounds from the early and middle Bronze age in North Brabant. (VAN ZEIST, 1967). It also applies to diagrams from small bogs in valley trains west of the Peel region (JANSSEN, in preparation). Also in the Belgian Kempen (MuNAUT, 1967) and in the lower Rhine region of western Germany (REHAGEN, 1964) the Subboreal values of Plantago lanceolata are low. In southern Limburg a culture phase with high values of Plantago lanceolata was observed during the Bronze age and later (JANSSEN, 1960). For the southern Limburg diagrams no ${ }^{14} \mathrm{C}$-dates were available and there remains the possibility that the culture phase postdates the Bronze age. But it is also possible, that man's activities were basically different from those to the west and north.

A striking feature in our diagrams is that the Ulmus minimum after the first land-occupation phase is quite low and that afterwards there is an almost complete regeneration. A similar feature in Ireland, in contrast to Scotland and England was explained by SMITH (1965, p.340) by favourable soil and climatic conditions. In Brabant neither soil nor climate (compared with England) are assumed to have been as favourable as in Ireland. Perhaps the kind of agricultural practice discussed before may be held responsible for the good regeneration of elm. It must be noted that similar percentages in different assemblage zones may mean a different actual number of deposition of elm grains. As a result the regeneration of elm may have been less complete than suggested by percentage curves.

\section{Fraxinus and Tilia}

The behaviour of the curves of Fraxinus and Tilia may be explained in two ways.

(1) The two species are components of humid floodplain forests (Ulmion). Fraxinus may spread rapidly by either rising water-levels in dry forests or by falling water-levels in wet forests. Falling water-levels may have been the reason for a rise of Fraxinus and a fall of Alnus in Denmark (IVERSEN, 1960, p.18). At Griendsveen there is a temporary rise of Alnus but at Ospelse Peel there is no change whatsoever. Thus there is in the Peel diagrams no clear relationship with edaphical factors.

(2) In the Peel diagrams the Fraxinus and Tilia curves follow faintly a similar trend as the Ulmus curve. This may indicate a connection with the landoccupation phases. Fraxinus is a heliophilous tree and it may expand as a result of forest clearance. According to VAN ZEIST (1959) Tilia and Fraxinus flower sooner than does Ulmus after cutting. This may account for the fact that the up and downs of the Tilia and Fraxinus curve are far less striking. 


\section{Pinus and Corylus}

At Griendsveen 2 there is a marked horizon (subzone VIIIb) characterized by a strong decrease of Corylus and Calluna, an increase of Pinus and Quercus and a slight increase of Fagus, Ulmus, Tilia and Fraxinus. At Ospelse Peel similar features are recognizable although to a lesser extent: there is no Quercus increase. What may be the explanation?

(1) The increase of Pinus may be due to local occurrence on the bog surface as a result of a shift in the water-balance of the bog. At Griendsveen there is at the base of the zone a marked change in the decomposition of the peat. The climate may have been responsible, for instance a shift towards a more continental climate would dessicate the bog surface and as a result Pinus would settle. The occurrence of pine in these habitats is not uncommon in continental regions (Ledo-Pinetum: Ellenberg, 1963). If we assume that Pinus occurs locally on the bog then it might be that the Corylus minimum is due largely to the pine rise. To investigate this, the percentages of Corylus and Quercus were recalculated on the basis of an upland pollen sum excluding Pinus (unexaggerated right hand curve in the Griendsveen 2 diagram). It appears that the general course of the curves for pollen grains of Quercus and Corylus are not affected by such a procedure. Moreover, in case of a dessication of the bog one would also expect an increase of Calluna. The contrary is true: Calluna is minimal during the subzone. The contradiction may be explained by differential dispersal. Low percentages of Calluna may arise when the species is not strictly local, because it does not disperse pollen very well. In contrast pine may have been present in close proximity and still show up in the diagram with raised values.

(2) The pine rise is of regional significance. One may assume that the pine reflects a regeneration of forest vegetation after land-occupation. Indeed in zone VIIlb culture indicators are low. The decrease of Corylus may be the result of forest expansion, especially of Quercus but also of other deciduous trees, even Fagus. The pine values below zone VIIIb are, compared with diagrams from other

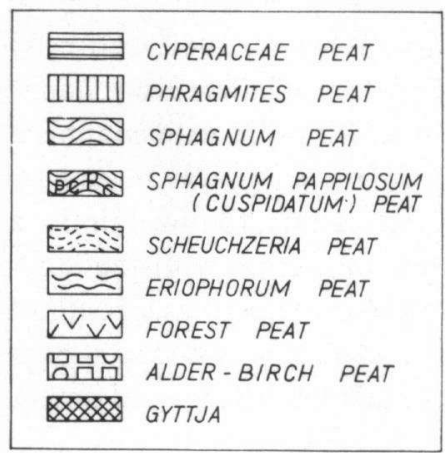

Fig.3. Peat symbols used in the pollen diagrams. 


$$
\text { If } \mathrm{II}_{\mathrm{x}} \mathrm{E}
$$




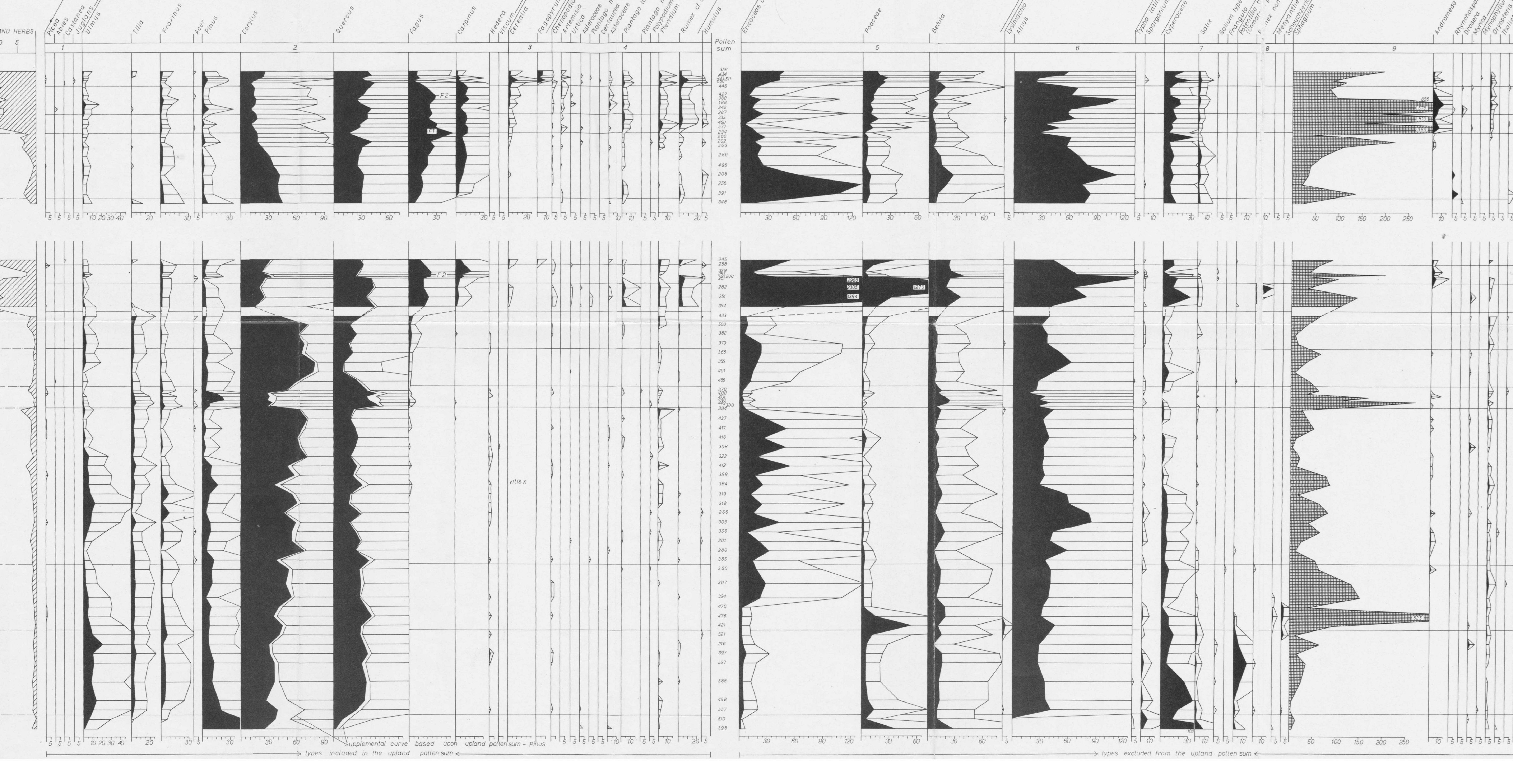


raised bogs (Ardennes, Drenthe) rather high. The pine curve shows striking fluctuations in the Atlantic and Subboreal period. These fluctuations are negatively correlated with Corylus and show some relationship with culture levels. Low values of pine occur at levels with maximum values for Corylus and upland herbs. Even in zone VIIId, there is a small pine rise during a minimum of culture indicators. The negative correlation of Pinus and Corylus is difficult to explain since both are apt to increase as pioneers after land-occupation. But perhaps part of the pine grains involved are transported by long distance and have their origin in other vegetation types.

Also the relationships of Corylus with land-occupation poses a problem. Generally Corylus rises markedly in pollen diagrams that show land-occupation of the Iversen type. Shifting agricultural practices apparantly were absent during the Subboreal in our region. One would expect, therefore, smaller percentages of Corylus.

The restriction of Polypodium to zone VIII may mean that the main tree that expanded in the forest is Quercus. Today Polypodium vulgare is abundant in Quercus woods. In a diagram from a site close to a dwelling place from the Vlaardingen culture (Voorschoten: GroenMAN-VAN WAATERINGE et al., 1968) a rise of Polypodium is seen in the regeneration phase. At any rate Polypodium becomes absent with the expansion of Fagus. Diagrams with close interval sampling and large pollen sums may eventually reveal some of these relationships.

\section{Subatlantic}

\section{Human activities}

The Subatlantic shows two clear land-occupation phases, now with many grains from the synanthropic group 4 . In between there is a considerable decline of man's activities. The ${ }^{14} \mathrm{C}$-dates indicate that this is the period of migration at the collapse of the Roman empire. Since the first report of this decline in the Untereichsfeld (STEINBERG, 1944), it has been shown in many diagrams, also in regions adjacent to the Peel (southern Limburg: JANSSEN, 1960; Belgian Brabant: MunAut, 1967; Westfalen: ReHAGEN, 1964). In the northern Netherlands the decline of human influence is generally absent, but it is noticeable in a diagram from eastern Friesland (Fochteloo: VAN ZeIST, 1955). KUBITZKI (1961) found it also in Schleswig-Holstein and northwestern Germany. Pollen grains of Secale make their first appearance in zone IXb and there is a strong rise of its curve during Medieval time. A similar pattern applies for the curve of Fagopyrum. It has been stated (LeHMANN, 1940) that this species has been introduced in Europe after 1400 A.D. MunaUt (1967) summarizes a number of sites in western Europe where Fagopyrum has been found before that time even in the Bronze and Iron ages. The occurrence of grains of Fagopyrum in zone $\mathrm{IXb}$ in our diagram agrees with these reports. 
Fagus

The first appearance of Fagus in the Peel diagram takes place at the transition zone VII/VIII, i.e., slightly before 2540 B.C. DRICOT (1960) and PERSCH (1950) obtained a similar date in the peatlands of the Hautes Fagnes. Also in central Belgium Fagus arrives at 2460 B.C. (Zandvliet: Munaur, 1967). Towards the north Fagus tends to appear later. In Drenthe the date is 2230 B.C. This fits the general picture of the migration of beech from southeast to northwest (FIrBas, 1949). During the Subboreal the Fagus values remain low. This is in contrast to southern Limburg and the Ardennes (MulleNDERs and KNOP, 1962). In zone IX, however, there is a rise of Fagus. In this zone the Fagus curve in many pollen diagrams from western Europe shows a number of fluctuations up to a number of four or five.

In central Belgium (MUNAUT, 1967), in southern Limburg (JANSSEN, 1960), in the Eifel (StrakA, 1960; Hummel, 1949) and in Luxemburg (Slotboom, 1963) two Fagus maxima are found. Already one of Eshuis' diagrams (Nieuwe Peel) shows the two maxima clearly. This applies also for the present data. At Ospelse Peel the two Fagus maxima were radiocarbon-dated. A first maximum (F-1) has been dated around the beginning of our era (GrN 5620: 140 B.C., GrN 5164: A.D. 65). This is close to the dates known from the Belgian Kempen and in high Belgium (Mullenders et al., 1967; Munaut, 1967; Dricot 1960; Gilot, 1963). As in Belgium the F-1 is synchroneous with or predates the extension of culture during the Roman period. The second Fagus maximum (F-2) gave a date of 1225 \pm 40 B.C. (GrN-5166), that is A.D. 725. Compared with high Belgium (MuLLENDERs et al., 1967) this is a few hundred years late but it is similar to the dates of PERSCH (1950). The F-3 and F-4 found in higher parts of Belgium are absent probably on account of the strong human influence upon the vegetation in Medieval time. The decline of Fagus in zone X certainly is a result of the big Medieval land reclamation which substitutes Fagus forests by fields and oak woods. However, the decline of Fagus after the F-1 can not be the result of human interference since the percentages of human indicators are decreasing between the two Fagus maxima. According to VAN ZEIST (1959) the rise of Fagus resulted from an increasing humidity. In our diagrams generally there is a corresponding rise of Alnus and Salix. At these levels in the Peel diagrams the Alnus and Salix grains found can not be of local origin and the variations of their curves have to be considered a regional feature. A rising phreatic surface in the Subatlantic may have resulted in an increase of the area available for lowland species. In this connection it is of interest that the Alnus curve (Ospelse Peel, Griendsveen) and the Salix curve (Griendsveen 1) show a negative correlation with the Fagus curve. A negative correlation of Alnus and Fagus is also noticeable in some of the diagrams of Eshuis (1946), in the eastern Netherlands (DANIELS, 1964), and in northwestern Germany (OverbecK and SCHNEIDER, 1938). Several explanations come up for discussion: 
(1) There is no actual change in the pollen deposition of Alnus and Salix. The maxima of these lowland elements are found at levels with low human activities. A regeneration of the upland resulted in a higher actual number of upland pollen grains and consequently in a relative suppression of the lowland elements.

(2) In Ireland a rise of Alnus during land-occupation phases is attributed by SMITH (1961) by selective activities of man. Man would have avoided lowland areas and as a result $A l n u s$ relatively increases. For the Peel diagrams this explanation seems less likely because Alnus is low during maxima of culture indicators. Still this effect may have played a role during minima of human interference.

(3) There may be a relationship with the groundwater level. The Fagus maxima would be present at times with a low water table. SLотвоом (1963) stresses the relationship of the Fagus maxima with regression periods. Although the relation between the phreatic surface and sealevels, if existing at all, is very complex the rise of Alnus between the F-1 and the F-2 may perhaps be connected with the Duinkerken 2 (Roman) transgression phase.

\section{DEVELOPMENT OF THE BOG VEGETATION}

At Ospelse Peel the local vegetation starts with a big maximum of Alnus and maxima of pollen of group 6. Via a maximum of Equisetum (fluviatile?) pollen grains of group 7 show a dominance in zone VIIb. In zone VIIc group 8 is most important in the diagram and in zone VIII, IX and $X$ we find representatives of group 9. A succession like this is quite familiar to us to-day. An alder carr (Alnion glutinosae) established itself on wet mineral soil. Pollen grains of associates of this community are present, also a seed of Lycopus. The number of lowland herbs, however, remains small, and we assume, therefore, that the Alnetum must have been quite dense. Soon, however, the alder carr gave way to a herb vegetation of mainly Dryopteris (spores) and Cyperaceae (seeds and pollen). Rhizomes of Phragmites are present as are seeds of Lycopus. This points to a rather rich vegetation type (Phragmitetea). But some representatives of a more acid vegetation are already present: Frangula (pollen), Betula (seeds, pollen) and Comarum palustre (fruits, pollen) begin to occur regularly. In zone VIIc there is a vegetation that looks much like the present Scheuchzerietalia. After this, in zone VIII and later the local vegetation consists of Sphagnum, Andromeda polifolia, Eriophorum, etc. We are dealing now with a true ombrogeneous bog vegetation. At Griendsveen 2 we find a similar succession except that an alder carr is absent at the base of the core. The succession immediately starts with poor fen.

Alder and birch carrs may have occurred at the margin of drainage channels where more eutrophic conditions existed. Indeed the Ospelse Peel site is close to the border of such a channel. In contrast, the site of Griendsveen 2 is located 
outside such a channel. Here peat development started on sandy soils with the poorer vegetation types.

In our diagrams the curve of Sphagnum, though rather irregular, shows some striking maxima that seem to occur at regular levels, one during zone VIIc, a second one during zone VIIIb, a third one during zone IXb, and a fourth at the bottom of zone $X$. They seem to occur where there is a change in peat stratigraphy. Peaks of Sphagnum associated with changes in peat humification are reported by Nichols (1967) in Canada and by Tallis (1964) in England. Apparently the production of Sphagnum spores depends on a change in the environment.

\section{ACKNOWLEDGEMENTS}

The authors are indebted to Mrs. E. H. Ten Bensel-Burger and Mr. H. A. M. Mekel for allowing them to use the pollen data from the Griendsveen sites. Thanks are extended to Dr. J. C. Vogel, ${ }^{14}$ C-Laboratory of the State University at Groningen for dating samples from one of the cores.

\section{REFERENCES}

Daniels, A. G. H., 1964. A contribution to the investigation of the Holocene history of the beech in the eastern Netherlands. Acta Botan. Neerl., 13: 66-75.

Dricot, E. M., 1960. Recherches palynologiques sur le plateau des Hautes-Fagnes. Bull. Soc. Roy. Botan. Belg., 92: 157-196.

EllenberG, H., 1963. Vegetation Mitteleuropas mit den Alpen. Einführung in die Phytologie 4(2). Eugen Ulmer, Stuttgart, $943 \mathrm{pp}$.

Eshuns, H. J., 1946. Palynologisch en Stratigraphisch Onderzoek van de Peel-venen. Thesis, State Univ., Utrecht, $143 \mathrm{pp}$.

FirBas, F., 1949. Spät- und Nacheiszeitliche Waldgeschichte Mitteleuropas nördlich der Alpen, 1. Allgemeine Waldgeschichte. Gustav Fischer, Jena, 480 pp.

GILOT, E., 1963. Louvain natural radiocarbon measurements, 6. Radiocarbon, 10: 55-60.

Groenman-Van WaAteringe, W., Voorrips, A. and Van WiJngaarden-Bakker, L. H., 1968. Settlements of the Vlaardingen culture at Voorschoten and Leidschendam (ecology). Helinium, 8: 105-130.

Hummel, H., 1949. Zur postglazialen Wald-, Siedlungs- und Moorgeschichte der Vordereifel. Planta, 37: 451-497.

IVERSEN, J., 1941. Land-occupation in Denmarks Stone age. Danmarks Geol. Undersøgelse II, 66: $1-68$.

IVERSEN, J., 1960. Problems of the early Postglacial forest development in Denmark. Danmarks Geol. Undersogelse IV, 4(3): 1-32.

JANSSEN, C. R., 1960. On the Late Glacial and Postglacial vegetation of south Limburg (Netherlands). Wentia, 4: 1-112.

JANsSEN, C. R., in preparation. Some Late Holocene diagrams from small bogs in the Dommel valley, North-Brabant (The Netherlands).

KuBITZKI, K., 1961. Zur Synchronisierung der Nordwest-europäischen Pollendiagramme (mit Beiträgen zur Waldgeschichte Nordwestdeutschlands). Flora, 150: 43-72.

Lehmann, H., 1940. Forschungsber. Deut. Landesk. (Leipzig), 35.

Mullenders, W. et Knop, C., 1962. La tourbière du Grand Passage. Bull. Soc. Roy. Botan. Belg., 94: 163-175. 
Mullenders, W., Gilot, E., Ancion, N. and Capron, P., 1967. Evolution of the vegetation in high Belgium and its radiocarbon chronology. In: E. J. CushING and H. E. WRight JR. (Editors), Quaternary Paleoecology-Proc. Intern. Quaternary Assoc., 7th, Boulder, 1965, 7: 333-339.

Munaut, A. V., 1967. Recherches paleo-écologiques en basse et moyenne Belgique. Acta Geograph. Lovaniensa, 6: 1-191.

Nichoss, H., 1967. The post-Glacial history of vegetation and climate at Ennadian Lake, Keewatin, and Lynn Lake, Manitoba (Canada). Eiszeitalter Gegenwart, 16: 176-197.

NiLsson, T., 1964. Standard pollendiagramme und ${ }^{14} \mathrm{C}$-datierungen aus dem Ageröds Mosse im Mittleren Schonen. Lund Univ. Arsskr., Avd. 2, 59(7): 1-52.

OVERBECK, F. und SCHNEIDER, S., 1938. Mooresuntersuchungen bei Lüneberg und bei Bremen und die Reliktnatur von Betula nana L. in Nordwestdeutschland. Z. Botan., 33: 1-54.

Persch, F., 1950. Zur Postglazialen Wald- und Moorentwicklung im Hohen Venn. Decheniana, 104: 1-81.

Rehagen, H. W., 1964. Zur Spät- und Postglazialen Vegetationsgeschichte des Niederrheingebietes und Westmünsterlandes. Fortschr. Geol. Rheinland Westfalen, 12: 55-96.

SLотвоом, R. T., 1963. Comparative Geomorphological and Palynological Investigation of the Pingos (Viviers) in the Hautes Fagnes (Belgium) and the Mardellen in the Gutland (Luxemburg). Thesis, Univ. of Amsterdam, $41 \mathrm{pp}$.

Smith, A. G., 1961. The Atlantic-Subboreal transition. Proc. Linnean Soc. London, 172: 38-49.

SMrTH, A. G., 1964. Problems in the study of the earliest agriculture in northern Ireland. Rept. VIth Intern. Congr. Quaternary, Warsaw, 1961, 2: 461-471.

SMrTH, A. G., 1965. Inertia and threshold related to Postglacial habitat changes. Proc. Roy. Soc. London, Ser. B, 161: 331-342.

SteInBerG, K., 1944. Zur Spät- und Nacheiszeitlichen Vegetationsgeschichte des Untereichsfelds. Hercynia, 3: 529-587.

StraKa, H., 1960. Zwei postglaziale Pollendiagramme aus dem Hinkelsmaar bei Manderscheid (Vulkaneifel). Decheniana, 112: 210-241.

TAllis, J. H., 1964. Studies on southern Pennine peats, 3. The behaviour of Sphagnum. J. Ecol., 52: 345-353.

Troels-Smith, J., 1955. Pollenanalytische Untersuchungen zu einigen Schweizerischen Pfahlbauproblemen. In: W. V. GUYAN (Herausgeber), Das Pfahlbauproblem. Birkhäuser, BaselSchaff hausen, pp. 11-58.

Van Regteren Altena, I. F., Bakker, J. A., Clason, A. I., Glasbergen, W., Groenman-Van WaAteringe, W. and Pons, L. J., 1962. The Vlaardingen cultures. Helenium, 2: 3-35.

VAN DER TOORN, C., 1967. Toelichting bij de Geologische Kaart van Nederland 1:50.000. Blad Venlo-West ( $52 W)$. Geol. Sticht., Afdel. Geol. Dienst, Haarlem, $163 \mathrm{pp}$.

VaN ZeIsT, W., 1955. Some radiocarbon dates from the raised bog near Emmen (Netherlands). Palaeohist. 4: 113-118.

VAN ZEIST, W., 1959. Studies on the post-Boreal vegetational history of southeastern Drenthe (Netherlands). Acta Botan. Neerl. 8: 156-185.

Van Zeist, W., 1967. Archaeology and palynology in The Netherlands. Rev. Palaeobotan. Palynol., 4: 45-67.

Waterbolk, H. T., 1954. De Praehistorische Mens en zijn Milieu. Thesis, State Univ., Groningen, 153 pp. 